\title{
147ste DESTUURSVERGADERING,
}

\author{
GEHOUDEN 15 MAART 1873.
}

'Tegenwoordig de heeren: Bleeker (Voorzitter), Wijnmalen, (Secretaris), Bachiene, Dumontier, 's Jacob, Kern, Meinsma en Niemann. Afwezig de heeren Sloet van de Beele, Millard, Blommendal en Hoffmann, de twee laatsten met kennisgeving.

De Voorzitter opent de vergadering en herinnert het verlies dat het Instituut en de wetenschap geleden hebben door het overlijden van den heer mr. P. A. S. van Limburg Brouwer.

De notulen van het verhandelde in de vorige vergadering worden gelezen en goedgekeurd.

De Voorzitter bericht de ontvangst van:

10. De volgende boekwerken:

Van het Departement van Koloniën :

Topographische kaart van de residentiën Samarang en Soerabaja.

Koloniaal Verslag over 1872.

Jaarboek van het Mijnwezen in Ned. O. I. 1• jaarg., 2e dl. Van het Bataviaasch Genootschap van Kunsten en Wetenschappen :

Verhandelingen, deel XXXVI.

Tijdschr. 6e serie, deel I, afl. 5 en 6 .

Notulen, deel X, no. 1-3.

Van de Koninklijke Academie van Wetenschappen te Amsterdam :

Verslagen en mededeelingen, afd. letterkunde, $3 \mathrm{e}$ dl., le stuk,

Vau het Koninklijk Instituut van Ingenieurs:

Tijdschrift, 1872-1873. 2e afl. 
Van den Minister van Koloniën en Marine, te Parịs :

De Lagrée et Garnier, Voyage d'exploration en Indo-Chine.

2 vol. avec cartes et plaus et album pittoresque.

Van de Akademie van Wetenschappen, te Berlijn :

Monatsbericht, Nov. 1872.

Van de Akademie van Wetenschappen, te Weenen:

Math. naturw. Classe 1873, no. 4-6.

Van de Gesellschaft der Wissenschaften, te Göttingen :

Nachrichten 1872.

Van prof. Angelo de Gubernatis.

La Rivista Europea. Afl. Maart 1873.

Van de Société d'ethnographie, te Parijs:

Actes, no. 24, en 25.

Prospectus en proefnummer van een nieuw geografisch tijdschrift in het Italiaansch, getiteld Cosmos.

20. De volgende missives:

a. van de heeren Corus. de Groot, G. F. C. Rose, Jhr. N. A. Holmberg de Beckfelt, G. J. Eschauzier, allen te 's Gravenhage, Gualth. Kolff te Leiden, Professor J. J. P. Valeton te Groningen, mr. F. M. C. Pels Rijcken te Arnhem, en Joost van Vollenhoven te Rotterdam, houdende bericht dat zij de benoeming tot lid van het Instituut aannemen.

Aanneming voor kemnisgeving.

b. Van Commissarissen van het Leesmuseum te Amsterdam, te kennen gevende, dat het hun aangenaam zou zijn, indien hun in het vervolg een exemplaar kon worden uitgereikt van de Bijjragen door het Instituut uitgegeven.

Dit verzoek wordt niet voor inwilliging vatbaar geoordeeld, Het reglement laat toch toe dat ook instellingen het lidmaatschap aanvaarden, zooals het geval is met het Nederlandsch bijbelgenootschap en het Nederlandsch zendelinggenootschap. Het zou eenigermate oubillijk zijn tegenover die contribueerende instellingen, indien men audere instellingen kosteloos een ex. der Bijdragen verstrekte. Op grond hiervan besluit de vergadering aan Commissarissen mede te deelen, dat het Instituut gaarne, indien het wordt verlangd, het Leesmuseum onder de contribueerende instellingen zal opnemen.

c. Van Commissarissen van het Instituut te Batavia dd. 14 
Januari 1873, waarbij wordt overgezonden een wissel groot $f 800$. - zijnde het bedrag der goevernements-bijdrage over het over het 2 e halfjaar 1872 ad $f 300$. - en eeue som van $f 500$.aan geinde contributie.

De outvangst vau dezen wissel, die bereids in handen van den penningmeester is gesteld, zal aan Commissarissen worden bericht.

Rapport over de opneming in de Bïdragen eener Engelsche verlaling van een Japansch staatsstuk, getiteld: The legacy of Jyéyás. De heer Hoffimann meent te kunnen verzekeren dat het stuk nog nergens is gedrukt. Toch ontraadt hij de opneming van het stuk in de Bijdragen, die daarvoor buitendien niet het geschikste orgaan zijn: 10 . omdat het stuk niet door of namens den vertaler aan het Instituut ter publicatie is aangeboden; 20. omdat de vertaler, de heer Lowder, als Britsch ambtenaar, in Britsche organen het veld voor de uitgave van zijn letterkundigen arbeid te zoeken heeft.

$\mathrm{Na}$ kennisneming van dit rapport besluit de vergadering de vertaling terug te zenden aan den heer A. Bauduin, die het door tusschenkomst van den heer van Soest aan het Instituut inzond, onder dankbetuiging voor de belangstelling, die het Instituut van de zijde des heeren Bauduin door de aanbieding der vertaling heeft mogen ondervinden.

Rapport omtrent de uitgave van dr. G. Schlegel's werk, getiteld: Uranographie Chinoise. De heer Kern verklaart dat hij, vooral na het zoo gunstig advies van deu heer Hoffinann, dat in de vorige vergadering werd uitgebracht, het voorstel tot uitgave van het werk ondersteunt. Ook de heer Blommendal is voor die uitgave gestemd.

De vergadering besluit met algemeene stemmen, dat het lustituut zich met de uitgave van het werk van den heer Schlegel zal belasten. Van dit besluit zal den auteur mededeeling worden gedaan.

Met het oog op de kosten aan de uitgave verbonden, meent de vergadering, dat het wenschelijk zal zịn de oplage niet al te gering te stellen. Alvorens die oplage te bepalen, wordt het nuttig geacht aan de Ministers vau Koloniëu, van Binnenen van Buitenlandsche Zaken mededeeling te doen van de aanstaande verschijning van het werk, met het verzoek om, zoo 
voor rekening van genoemde departementen een eenigszins belangrijk getal exx. van dit werk mocht worden verlangd, daarvan thans reeds opgave te willen doen, om daarop bij de bepaling der oplage te kunnen rekenen.

\section{Rapport omtrent de plaatsing in de Bijdragen van een opstel} van den heer Leupe over Salomon Sweerts. De heer Meinsma verklaart van dit opstel met belangstelling kennis te hebben genomen. Het bevat eenige tot nu toe minder bekende bijzonderheden omtrent dezen persoon en zijne verhouding tot de overige Raden van Indië. Vooral belangrijk is de memorie van zijne hand, na zijne terugkomst in Holland aan bewindhebbers der Compagnie ingediend, waarin hij betoogt, dat, moge hij zich aan overtreding van de bevelen van bewindhebbers hebben schuldig gemaakt, dit in nog veel grooter mate het geval is met de overige machthebbende personen in Indië. Wij leeren daaruit welk eene uitgebreidheid toen reeds de misbruiken, die met de compagnie geboren, ja bijna als onafscheidelijk van het bestaan van zoodanig lichaam moeten worden beschouwd, hadden verkregen. Al is slechts de helft waar van al hetgeen Sweerts tegen zijne ambtgenooten in de Hooge Regeering van Ned. Indië inbrengt, dan kan de toestand toch niet anders dan treurig worden genoemd. Misschien verdient de memorie ook nog daarom de aandacht, dewijl zij kan hebben medegewerkt tot het wantrouwen dat de bewiudhebbers van de compagnie bij menige gelegenheid jegeus van der Lijn te kennen gaven. Jammer slechts dat de stijl van den eerbaren Salomon Sweerts niet zeer nauwkeurig, is, zoodat zijne memorie wel wat vermoeiend is om te lezen.

De heer Meinsma adviseert tot plaatsing van het opstel in de Bijdragen, onder voorwaarde evenwel dat de inleiding van den heer Jueupe met eenige bekorting en de memorie zelve met eenige uitlatingen opgenomen worden.

Overeenkomstig dit advies besluit de vergadering tot plaatsing van het opstel in de Bijdragen, met inachtneming evenwel der opmerkingen van den heer Meinsma.

\section{Transcriptie van Javaansch, Arabisch, Nägari en ander letterschrift.}

De. heer Kern zegt dat hij een concept-rapport heeft opgesteld en dit aan de goedkeuring der verschillende leden van de commissie heeft onderworpen. Dat concept mocht evenwel de 
goedkeuring der' leden niet verwerven, zoodat hij meent wel te doen, ten einde de verschillende meeningen te leeren kennen, zoowel het concept als de schriftelijke adviezen der leden van de commissie, mede te deelen.

Het door den heer Kern geleverd concept is van den volgenden inhoud:

"Zoo de commissie voor de transcriptie van Javaansch, Arabisch, Nâgari en ander letterschrift lang gewacht heeft met haar verslag, dan is zulks niet zonder opzet geschied. Toen ruim een jaar geleden een stelsel van transcriptie voor 't tijdschrift werd voorgesteld, was er eene uitnoodiging aan alle belangstellenden bijgevoegd om voorslagen ter verbetering of bedenkingen mede te deelen. Aan die uitnoodiging werd weinig gehoor gegeven. Alleen de heer Juynboll gaf in eene algemeene vergadering eenige verbeteringen aan de hand, terwijl professor Roorda een schrijven inzond, waarin hij de opmerkzaamheid vestigde op in de tabel ingeslopen fouten, en voorts verklaarde te moeten opkomen tegen den dwang die, door 't verbindend verklaren van één stelsel, den schrijvers werd opgelegd. In werkelijkheid lag het niet in de bedoeling der commissie de vrijheid der inzenders op 't stuk van spelling aan banden te leggen, en 't spijt haar dat enkele minder gelukkig gekozen uitdrukkingen in 't bij de tabel gevoegde verslag aanleiding tot eenige onjuiste veronderstellingen hebben gegeven. De hoofdzaak -- zoo meende de commissie - was: een stelsel voor transcriptie van grootere teksten te ontwerpen en daarvan eene proeve te geven, waaruit blijken kon, hoe men de aan het Romeinsche alfabet ontbrekende letterteekens met behulp van punten en anderzins vermocht uit te drukken. De commissie liet zich leiden door de gedachte dat door 't bezigen van de in alle drukkerijen voorhanden letters, vermeerderd met eenige weinige andere, voorzien van eenige diacritische punten, de kosten van 't drukken aanmerkelijk verminderen moesten, terwijl bij volslagen gebrek aan typen 't mededeelen van een tekst in Nâgari zelfs tot de onmogelijkheden behoorde. Wat nu de vrijheid der schrijvers aangaat, kon er van den kant des Instituuts geen bezwaar bestaan, als iemand zich bedienen wilde van eene transcriptie en spelling, die niet in allen deele met de voorgestelde overeenkwamen, mits zoo iemand geen teekens bezigde, welke nog opzettelijk gegoten moesten worden. Behalve de heeren Juynboll en Roorda hebben zich geene andere stemmen doen hooren. Het 
is echter genoegzaam gebleken dat de behoefte aan een stelsel van transcriptie slechts door weinigen gevoeld, of de wenschelijkheid er van erkend wordt, want ettelijke bijdragen ingezonden na 't tijdstip, waarop de tabel verscheen, bevatten uitvoerige teksten in oostersch letterschrift of wel in een in beginsel afwijkend stelsel van transcriptie. Nu gevoelt de commissie geene vrijheid aan 't Bestuur voor te stellen dat een door haar ontworpen stelsel voortaan streng verbindend worde verklaard voor alle stukken in de Bijdragen en een nieuw, verbeterd stelsel met moeite en veel tijdverlies op te maken, heeft geen nut. In den boezem der commissie heerscht volkomen eenstemmigheid èn in de hoofdbeginselen èn in de onderdeelen, en indien hare leden de vraag te beantwoorden hadden of zij het onderling eens waren over de doelmatigste transcriptie, zouden zij een toestemmend antwoord geven. Maar zij achten het in de gegeven omstandigheden doelloos, in plaats van de vroeger gedrukte tabel een nieuwe in te leveren, waarop wel is waar de ingeslopen fouten zouden verbeterd zijn, maar waarvan 't beginsel niet van de vorige zou verschillen. Deze overwegingen hebben de commissie geleid tot de slotsom welke zij aan het oordeel van het Bestuur onderwerpt: het blijve aan de keuze der inzenders van stukken overgelaten die transcriptie te bezigen welke hun 't beste behaagt, zooals dan ook in de practijk tot nu toe steeds 't geval is geweest."

Naar aanleiding van dit concept-rapport deelde de heer Meinsma - mede:

"De ondergeteekende kan zich niet geheel vereenigen met het door den heer Kern ontworpen rapport der commissie voor de transcriptie. Hij wenscht wel ieder volkomen vrịheid te laten om zijn eigen systeem te gebruiken, maar is van meening dat de zaak nog een anderen kant ter overweging aanbiedt, waarom hij zich moet verklaren tegen de voorgestelde onthouding van het geven van een outwerp. $\mathrm{Nu}$ eenmaal stappen gedaan zijn op den weg en een stelsel namens het Instituut in de Bijdragen het licht heeft gezien, waarop nog al aanmerkingen werden gemaakt, acht de ondergeteekende het voor de eer van het Instituut wenschelijk, dat een nieuw ontwerp worde publiek gemaakt; natuurlijk moet dan overgelaten worden of men er zich van wil bedienen of niet. Hij zou daarom voorstellen het door de commissie in het vorig jaar ontworpen stelsel, nevens dat van deu hoogleeraar Roorda, waarvau inzage is verleend, eu welke beide 
stukken indertijd door hem aan professor Kern zijn teruggezonden, het bestuur aan te bieden en daarvoor eene plaatsing in de Bijdragen te verzoeken en daarmede de zaak als afgedaan te beschouwen."

Het gevoelen van den heer Juynboll is aldus geformuleerd: "Even als de heer Meinsma neem ik de vrijheid om op 't concept van professor Kern, dat ik overigens in het algemeen goedkeur, eenige bedenkingen -- bijvoegsels - mee te deelen, die mij voorkomen zelfs in de bedoeling van den steller te zijn. Ik zou de zinsnede, aldus aanvangende: " $\mathrm{Nu}$ gevoelt de commissie geene vrijheid enz." willen lezen: "Nu gevoelt de commissie, die laatst van 't Bestuur de opdracht ontving tot het maken van een nieuw transcriptie-systeem, geene vrijheid aan u voor te stelleu enz." En aan 't einde zou ik dit slot wenschen, dat door den steller in der haast schijnt vergeten te zijn: "Opdat ieder in de gelegenheid gesteld zij, zoodanig te transcribeeren als 't hem behaagt, zou 't Bestuur dus slechts te zorgen hebben dat een genoegzaam aantal Romeinsche letters voorhanden kome, voorzien met die bijgevoegde teekens, welke volgens veler inzicht noodig zijn om kort en oubedriegelijk duidelijk de verschillende vreemde letterteekens weer te geven; zoo lang toch deze voor velen dringende behoefte niet vervuld is, heeft 't Bestuur hun de gelegenheid niet opengesteld om op hunne wijs, - d. i. ieder vrij naar eigen verkiezing en inzicht ten dezen opzichte te handelen. Wellicht kan 't Bestuur dan later anleiding vinden om desverkiezende 't eenvoudigste systeem, als 't doelmatigste, aan de belangstellende inzenders vau bijdragen an te bevelen."

De heer Gouggrijp heeft het volgende verklaard:

"Ik vind de door den heer Juynboll gewenschte bijvoeging wel goed, alleen spijt het mij dat ik niet vroeger bekend geweest ben met een opstel van den heer Holle over transcriptie van 't Soendasch, voorkomende in deel XX, afl. 2 van 't Tijdschrift voor Indische taal-, land- en volkenkunde, onder redactie van mr. Stortenbeker."

Nadat de heer Meinsma kennis genomen had van het schriftelijk advies des heeren Juynboll, heeft eerstgenoemde nog het volgende medegedeeld :

"Ook na lezing van het advies van den heer Juynboll, unoet ik bij mijn voorstel blijven persisteeren, immers het aaninaken van diacritische punten zou weinig nut doen, wanneer men niet kent het systeem waarnaar zij moeten worden gebruikt. De door den hees 3e Volgr. VIII. 
Juynboll voorgestelde bijvoeging aan het slot acht ik derhalve onnoodig, tenzij eerst gevolg worde gegeven aan mijn voorstel."

De' heer Niemann, die niet in de gelegenheid is geweest, schriftelijk zijn gevoelen te doen kennen, verklaart dat het ook hem noodzakelijk voorkomt dat er iets gedaan worde, daar door de vergadering het besluit is genomen om voor de tabel, die in de Bijdragen is afgedrukt, eene andere in de plaats te stellen. $\mathrm{Hij}$ ondersteunt het gevoelen van den heer Meinsma om het door de Commissie ontworpen stelsel, benevens dat van den heer Roorda, in de Bijdragen te doen opnemen.

De heer Kern was anvankelijk ook van de meening des heeren Meinsma en Niemann, maar hij is daarvan teruggekomen, omdat wanneer in de Bijdragen twee stelsels, dat van de commissie en dat van den heer Roorda, worden aanbevolen, men alle andere, misschien even goede, stelsels uitsluit. De heer Kern erkent eenigermate de juistheid van het gevoelen des heeren Meinsma om nu eenmaal het Instituut die zaak ondernomeu heeft, de behandeling voort te zetten, maar hij meent dat het werk, daaraan besteed, vergeefsch zal zijn.

De Voorzitter meent dat de vergadering nu wel bekend is gemaakt met de individueele gevoelens van de leden der commissie, maar dat de vergadering van haar geen voorstel ontvangen heeft. Dit toch is wenschelijk, waut wanneer het voor de commissie moeilijk is tot een besluit te komen, die moeilijkheid is nog grooter voor de vergadering.

Op voorstel van den Voorzitter wordt de commissie diligent verklaard, met verzoek een bepaald voorstel aan het oordeel der vergadering te onderwerpen.

De Secretaris doet voorlezing van het verslag van den staat en de werkzaamheden van het Instituut in 1872 , dat namens het Bestuur op de aanstaande algemeene vergadering zal worden uitgebracht. Omtrent het concept-verslag worden eeuige opmerkingen in het midden gebracht, in welken geest het door den Secretaris zal worden gewijzigd.

De Penningmeester legt over zijne rekening en verantwoording over 1872. Op uitnoodiging van den Voorzitter verklaren de heeren 's Jacob en Dumontier zich bereid die rekening te onderzoeken en van huu bevinding verslag te doen vóór de aanstaande algemeene vergadering. 